\title{
Construction Waste Estimation Analysis in Residential Projects of Malaysia
}

\author{
Kumanan Kupusamy \\ Department of Building \& Construction \\ Engineering, University Tun Hussein \\ Onn Malaysia, Batu Pahat, Malaysia \\ k.kumanankupusamy@gmail.com
}

\author{
Sasitharan Nagapan \\ Department of Building \& Construction \\ Engineering, University Tun Hussein Onn \\ Malaysia, Batu Pahat, Malaysia \\ sasitharan@uthm.edu.my
}

\author{
Abd Halid Abdullah \\ Department of Building \& Construction \\ Engineering, University Tun Hussein \\ Onn Malaysia, Batu Pahat, Malaysia \\ abdhalid@uthm.edu.my
}

\author{
Suaathi Kaliannan \\ Department of Building \& Construction Engineering, \\ University Tun Hussein Onn Malaysia, \\ Batu Pahat, Malaysia \\ suaathikaliannan@gmail.com
}

Shivaraj Subramaniam

Department of Building \& Construction Engineering, University Tun Hussein Onn Malaysia, Batu Pahat, Malaysia shivaraj103@gmail.com

\author{
Samiullah Sohu \\ Department of Civil Engineering. \\ Quaid-e-Awam University of Engineering, Science \& \\ Technology, Campus Larkana, Pakistan \\ sohoosamiullah@gmail.com \\ Haritharan Maniam \\ Department of Building \& Construction Engineering, \\ University Tun Hussein Onn Malaysia, Batu Pahat, Malaysia \\ haritharanmaniam@gmail.com
}

\begin{abstract}
Construction and demolition (C\&D) waste account for an oversized share of all solid waste generated worldwide. Statistical data confirm that, globally, $10-30 \%$ of waste originates from construction and demolition works. The types of waste from construction activities are wood, metals, concrete waste and mixed wastes. Waste generation continues to increase with the economy and population growth. A great challenge is providing more waste disposal facilities such as landfills to treat the waste. Rapid urbanization and insufficient attention to $C \& D$ waste generation, particularly in developing countries like Malaysia, have contributed to an urgent need for additional research on waste generation as there is a lack of information. The aim of this study is to predict the construction waste generation for the peninsular of Malaysia by quantifying construction waste generation data for Kuala Lumpur and to estimate the construction waste generation in 2016 for the peninsular of Malaysia. The estimation approach used was the proportion method with $20 \%$ of total sites in each state. Indirect waste measurement method was used to estimate waste generation. Total waste generation for Kuala Lumpur was around 6,101.46 metric tons. The predicted total amount of $C \& D$ waste generated for residential projects throughout Malaysia Peninsular is $63,101.93$ metric tons. The initial prediction of construction waste generation for Malaysia Peninsular can be used as a baseline for future study.
\end{abstract}

\section{Keywords-construction; waste; estimation; proportional}

\section{INTRODUCTION}

Construction and demolition (C\&D) waste is produced during construction, renovation, and demolition of buildings and structures. Construction waste is anything generated as a result of construction and then abandoned, regardless of whether it has been processed or stockpiled. It comprises of surplus materials from site clearance, excavation, construction, refurbishment, renovation, demolition and road works. Construction industry is a key part in the economy of any country. In Malaysia, this industry has been playing a vital role in economy's growth [1]. Nowadays, construction industry is quickly developing as a result of the modernization in the way of life, demands of infrastructure projects, changes in consumption habits, and the population increment [2]. The construction industry is commonly environmentally unfavorable [3]. C\&D waste account for an oversized share of total solid waste generated worldwide. This industry contributes significantly to the environmental problem in terms of natural resources exploration, irreversible transformation of the natural environment and accumulation of pollutants in the atmosphere [4]. Construction waste is generated throughout the construction process, during site clearance, material damage, material use, material non-use, excess procurement and human errors. Moreover, statistical data confirm that $10-30 \%$ of total waste is originated from construction and demolition works [5]. The main types of waste from construction activities are wood, metals, concrete waste, plastics, papers and cardboards, glass, hazardous wastes (such as paints and glues), etc.[6].

Construction waste is produced through the project from pre-construction stage, rough construction stage and finishing stage. Generation of construction waste can be caused by various factors. It is vital to recognize and comprehend those causes for controlling waste generation at its source [7]. Causes of construction waste generation on-site are: lack of skills and 
experience of construction workers, lack of skills and experience of demolition contractors, wasteful use of materials in construction activities, inappropriate methods for loading and shipment of building materials from suppliers to sites, inappropriate methods for handling building materials on-site, frequent demolitions due to reworks and change of orders, traditional methods of construction, inappropriate packaging of building materials and components, inappropriate inventory of building materials and components, and low quality of buildings materials and components. There is still a lack of data on construction waste generation for Malaysia. Field measurement research on construction waste generation is negligible in Malaysia. Questionnaire based data are less accurate because they draw conclusions from individual assumptions on waste generation without proper evidence and data. Moreover, the research done by previous researchers mainly focuses on specific sites and does not include state or county wide data. Field measurement data will be more accurate on construction waste compared to questionnaire survey data.

\section{CONSTRUCTION WASTE CATEGORIES}

Construction waste is classified by source and type. In order to quantify the construction waste adequately, it is useful to have a classification of wastes by source and type of generated waste [8]. Hence, waste generated on the construction site can be classified in the following two classes:

- Building waste, generated during the construction process due to defects, damages, breakage or simply due to excess.

- Packaging waste generated from packaging of materials and products delivered to construction site.

The main types of waste from construction activities are wood, metals, mineral debris (such as stone, bricks, mortar and concrete), plastics, papers and cardboards, glass, and hazardous waste (such as paints and glues).

\section{THE CONSTRUCTION WASTE ISSUE IN OTHER COUNTRIES}

Various minimization programs have been conducted to enhance sustainability in construction. In Australia, the C\&D waste accounts for $16-40 \%$ of total solid generated waste. A total of 19.0 million tons of C\&D waste had been produced in Australia in 2008-2009, out of which 8.5 million tons were disposed to landfills while 10.5 million tons, or $55 \%$, was recovered and recycled [9]. In Romania, the C\&D waste was the $4 \%$ of the total in $2003,10 \%$ in 2004 and $7 \%$ in 2005 . In total amounts, the quantity of C\&D produced waste in 2004 was 646,400 tons and dropped in 2005 to 466,893 tons [10]. In USA, 136 million tons of building-related $\mathrm{C} \& \mathrm{D}$ debris are generated each year [11], out of which only $20-30 \%$ is recycled [12]. In the UK, every year around 70 million tons of C\&D materials and soil end up as waste [13], and the wastage rate in the UK construction industry is as high as 10-15\% [14]. The waste amount from C\&D activities has remained at around 100 million tons annually in recent years, while demolition accounted for around 32.7 million tons in 2007, which means demolition waste takes about $30 \%$ of all annual construction generated waste [15]. In Tehran, Iran about 18,250,000 tons of C\&D waste is produced annually [16]. In China, according to the report by the Environment Protection Department (EPD), about 2900 tons of C\&D waste were received at landfills per day in 2007 . China produces $29 \%$ of the world's municipal solid waste (MSW) each year, with nearly $40 \%$ of this amount produced by construction activities [17]. In Japan, the amount of construction waste dropped from 99 million tons to 77 million tons in a ten-year period (1995-2005), while the recycling rate increased from $58 \%$ to $92 \%$ in the same period [4].

\section{CONSTRUCTION WASTE IN MALAYSIA}

Malaysia has experienced a quick infrastructure development over the last decade. C\&D waste constitutes around $20 \%$ to $30 \%$ of the total waste in landfills. The amount of demolition waste is double the amount of construction waste. Construction waste management has become an issue that needs high concern in many developing countries because it has an adverse effect on economy, environment and social aspects [7]. Illegal dumping is a common issue and also a solution for contractors who deal in Malaysia [18]. Construction Industry Development Board (CIDB), mainly focuses on solid waste [7]. There are poor regulations and guidelines managing the $\mathrm{C} \& \mathrm{D}$ waste generation in Malaysia. In this manner, a satisfactory conclusion about C\&D waste management must be determined. There is no reliable data and information related to construction waste in Malaysia. In addition, Malaysia still lacks researches on construction waste generation [19].

\section{WASTE AMOUNT ESTIMATION}

Waste quantification utilized site accounting, record keeping, and waste characterization to recognize the creation of construction waste. It was a mean to estimate the quantity of generated construction waste, thus, assessing the potential for waste reduction. Waste quantification can also help in decision making in assessing the feasibility of recycling programs as practiced in countries like the USA, Hong Kong, and Taiwan. Nonetheless, Malaysia was yet falling behind in establishing the quantified benchmark for construction waste generation rate among its contractors as compared to other countries [17]. Site visiting and field measurements were used to investigate the waste generation rates. Field measurement surveys, in direct or indirect approaches can be utilized to collect C\&D waste generation data. Direct measurements require the weighting of the waste produced or to measure on site its volume. Indirect measurements are frequently used for practical estimations.

\section{RESEARCH METHODOLOGY}

Indirect measurements were used. Authors in [20] employed truck load records to estimate the volume of C\&D waste generated on site. They recorded the number of trucks for waste collecting and the containers' volume for deriving total waste volume at a project level. For the purpose of indirect quantification at a regional level, authors in [21] obtained truck load records from landfills. Mix waste data were calculated based on bin measurements and waste bin trips per day or week depending on the amount of the waste produced in site. After that, month data were calculated based on the 
addiction of daily and weekly data. This process was repeated for the twelve months of the year. With limited data available, cross-proportion method [21] deemed appropriate to be adopted in predicting the total construction generated waste [22].

\section{DATA COLLECTION AND ANALYSIS}

According to the data from CIDB in 2015, Kuala Lumpur is one of leading states in Malaysia in construction development. Construction waste in Kuala Lumpur is managed by the local authorities. This research focuses on construction waste generation mainly for residential type of projects. The residential sector in the city is growing rapidly in line with supply and demand of the population [23]. However, the produced waste is mixed in the majority sites and not separated according to respective types. Indirect data were collected from 38 sites during 2016. The data were taken from delivery orders by construction waste truck loads. The average tonnage of the waste generation for Kuala Lumpur was calculated. Based on the data, the estimation of waste generation for other states in Malaysia Peninsular was calculated. Table I shows the total data collection for Kuala Lumpur residential projects in 2016 (1-year period). The data were taken by using indirect methods. Thirty eight sites were visited for data collection in the Kuala Lumpur region. Waste quantification was high in January of 2016 (699.7633 tons), July (857.192 tons) and September (725.1662 tons). Waste generation was less than 500 tons the other months. The month with the lowest waste production was April and July had the highest production.

TABLE I. TOTAL DATA COLLECTION FOR KUALA LUMPUR

\begin{tabular}{|c|c|}
\hline Month & Average (tons) \\
\hline Jan & 699.7633 \\
\hline Feb & 312.0925 \\
\hline Mac & 378.054 \\
\hline Apr & 194.34 \\
\hline May & 326.044 \\
\hline Jun & 352.5443 \\
\hline July & 857.192 \\
\hline Aug & 363.608 \\
\hline Sept & 725.1662 \\
\hline Oct & 405.8421 \\
\hline Nov & 411.632 \\
\hline Dec & 311.7453 \\
\hline
\end{tabular}

Apparently, the total number of construction projects for each state was important in estimating the required number of samples using the cross-proportion method. CIDB has published a statistic for construction projects in Malaysia in 2015. Using the number of project sites in Kuala Lumpur which were measured through the indirect measurement method, the number of required project sites to be measured in other states can be estimated. Employing the cross-proportion method, the basic mathematical formula to determine the proportionate total weight of $C \& D$ waste for another state relative to the total weight of $C \& D$ waste was obtained. The basic mathematical formula used in the cross-proportion method to determine the proportionate number of estimated project sites to be measured in another state relative to the number of project sites measured in a certain state is (1) :

$$
\frac{c_{1}}{q_{1}}=\frac{c_{2}}{q_{2}}
$$

where $c_{1}$ is the number of project sites measured in a certain state, $c_{2}$ it the number of estimated project sites to be measured in another state, $q_{1}$ is the total number of project sites in a certain state, and $q_{2}$ is the total number of project sites in another state.

Using the number of project sites in Kuala Lumpur which were measured through indirect measurement method (i.e. 38 sites), and the total number of project sites in Kuala Lumpur (190) and Johor (350), the number of required project sites to be measured in the State of Johor can be estimated using (1) as $c_{2}=70$ sites. Therefore, 70 project sites in Johor should be measured in order to be proportionate to the 38 project sites measured in Kuala Lumpur. Employing the cross-proportion method, the basic mathematical formula to determine the proportionate total weight of $C \& D$ waste (i.e. based on the required number of project sites) for another state relative to the total weight of $C \& D$ waste (i.e. based on the number of project sites measured) obtained in a certain state is shown in (2) as:

$$
\frac{T_{1}}{c_{1}}=\frac{T_{2}}{c_{2}}
$$

where $T_{1}$ is the total tonnage of C\&D waste in a certain state (i.e. based on the number of project sites measured), $T_{2}$ is the total tonnage of C\&D waste estimated in another state (i.e. based on the number of estimated project sites to be measured), $c_{1}$ is the number of project sites measured in a certain state, and $c 2$ the number of estimated project sites to be measured in another state.

Therefore, the total weight of $C \& D$ waste generated (i.e. based on the number of estimated project sites to be measured) in the State of Johor can be estimated using (2) as:

$$
\begin{gathered}
6,101.46 / 38=T_{2} / 70 \\
T_{2}=11239.53 \text { metric tons. }
\end{gathered}
$$

Based on the limited data collected in Kuala Lumpur, the rough assumption and prediction using cross-proportion method has been made to generate the value of estimated C\&D waste generated in terms of tonnage for the 12 states of the Malaysia Peninsular. It is worth noting that the estimated amount obtained represents only $20 \%$ of the total residential project sites in each state. Table II shows that the predicted total amount of C\&D waste generated for residential projects throughout Peninsular Malaysia was 600,727.39 metric tons, which was based on the $20 \%$ of the total project sites considered in each state. It was shown that Selangor was the highest waste generator in the residential projects with 142156.86 tons in the year 2016, followed by Johor with 106999.79 tons. The least waste was generated in Perlis (4585.71 tons) and Kedah (30571.37 tons). Malaysian industrial areas such as Selangor and Johor produce more waste than less developed states such as Perlis. 
TABLE II. PREDICTED ANNUAL AMOUNT OF C\&D WASTE IN MALAY SIA PENINSULAR

\begin{tabular}{|c|c|}
\hline State & Predicted waste (tons) \\
\hline Wilayah Persekutuan & 58085.60 \\
\hline Johor & 106999.79 \\
\hline Kedah & 30571.37 \\
\hline Kelantan & 10699.98 \\
\hline Melaka & 25985.66 \\
\hline Negeri Sembilan & 48914.19 \\
\hline Pahang & 48914.19 \\
\hline Pulau Pinang & 56557.03 \\
\hline Perak & 50442.76 \\
\hline Perlis & 4585.71 \\
\hline Selangor & 142156.86 \\
\hline Terengganu & 16814.25 \\
\hline Total & $\mathbf{6 0 0 , 7 2 7 . 3 9}$ \\
\hline
\end{tabular}

\section{CONCLUSION}

This study successfully achieved its aim of predicting the construction waste generation for the Malaysian peninsular. There is a limited number of studies conducted on this field. Using the proportion methodology along with indirect measurements, this research had done the estimation of waste generation for residential projects in Peninsular Malaysia using Kuala Lumpur field measurement data. However, the projection of data includes the $20 \%$ of construction waste sites in Kuala Lumpur and other states. The predicted total annual amount of construction waste generated for residential projects throughout Peninsular Malaysia was 600,727.39 metric tons. It is shown that Selangor was the highest waste generator in the residential projects in 2016, followed by Johor. The least waste were generated in Perlis and Kedah, because industrial areas produce more waste than less developed states. This study had done the initial prediction by visiting and taking measurements on the $20 \%$ of the construction sites. In the future, this percentage could be augmented.

\section{ACKNOWLEDGEMENT}

Authors would like to thank the CIDB and the Solid Waste and Public Cleansing Management Corporation (SWCorp) for the information provided in this study. Also, the Universiti Tun Hussein Onn Malaysia and the Ministry of Education, Malaysia. Funds for the study were provided by the Fundamental Research Grant Scheme (FRGS) No.1624, and Grant No. U704.

\section{REFERENCES}

[1] M. F. Hasmori, I. Said, R. Deraman, N. H. Abas, S. Nagapan, M. H. Ismail, F. S. Khalid, A. F. Roslan, "Significant factors of construction delays among contractors in Klang Valley and its mitigation", International Journal of Integrated Engineering, Vol. 10, No. 2, pp. 3236,2018

[2] S. Nagapan, I. A. Rahman, A. Asmi, A. H. Memon, I. Latif, "Issues on Construction Waste: The Need for Sustainable Waste Management", IEEE Colloquium on Humanities, Science and Engineering, Kota Kinabalu, Malaysia, December 3-4, 2012

[3] S. Nagapan, S. Kaliannan, A. H. Abdullah, S. Sohu, R. Deraman, M. F. Hasmori, N. H Abas, "Preliminary survey on the crucial root causes of material waste generation in Malaysian construction industry", Vol. 8, No. 6, pp. 3580-3584, 2018

[4] A. P. Kern, M. F. Dias, M. P. Kulakowski, L. P. Gomes, "Waste generated in high-rise buildings construction: A quantification model based on statistical multiple regression”, Waste Management, Vol. 39, pp. 35-44, 2015

[5] M. F. B. Yusof, Study on Construction \& Demolition Waste Management in Construction Site, BSc Thesis, University College of Engineering \& Technology Malaysia, 2006

[6] S. Jalali, "Quantification of construction waste amount", available at: https://core.ac.uk/download/pdf/55608453.pdf, 2007

[7] S. Nagapan, I. A. Rahman, A. Asmi, A. H. Memon, R. M. Zin, "Identifying causes of construction waste-case of central region of Peninsula Malaysia", International Journal of Integrated Engineering, Vol. 4, No. 2, pp. 22-28, 2012

[8] A. F. Masudi, C. R. C. Hassan, N. Z. Mahmood, S. N. Mokhtar, N. M. Sulaiman, "Waste quantification models for estimation of construction and demolition waste generation: A review", International Journal of Global Environmental Issues, Vol. 12, No. 2-4, pp. 269-281, 2012

[9] S. Zakar, Overview of Demolition Waste in the UK, BRE, 2009

[10] O. F. Kofoworola, S. H. Gheewala, "Estimation of construction waste generation and management in Thailand", Waste Management, Vol. 29, No. 2, pp. 731-738, 2010

[11] K. Sandler, P. Swingle, OSWER Innovations Pilot: Building Deconstruction and Reuse, EPA 2006

[12] A. A. Najafpoor, A. Zarei, F. J. Behnam, M. V. Shahroudi, A. Zarei, “A study identifying causes of construction waste production and applying safety management on construction site", Iranian Journal of Health Sciences, Vol. 2, No. 3, pp. 49-54, 2014

[13] Waste Strategy 2000 for England and Wales, Crown, 2000

[14] C. McGrath, M. Anderson, "Waste minimizing on a construction site", Building Research Establishment Digest, Vol. 447, pp. 441-454, 2000

[15] X. Chen, W. Lu, "Identifying factors influencing demolition waste generation in Hong Kong", Journal of Cleaner Production, Vol. 141, pp. 799-811, 2017

[16] B. R. Broujeni, G. A. Omrani, R. Naghavi, S. S. Afraseyabi, "Construction and demolition waste management (Tehran case study)", Engineering Technology \& Applied Science Research, Vol. 6, No. 6, pp. 1249-1252, 2016

[17] H. Wu, H. Duan, L. Zheng, J. Wang, Y. Niu, G. Zhang, "Demolition waste generation and recycling potentials in a rapidly developing flagship megacity of South China: Prospective scenarios and implications", Construction and Building Materials, Vol. 113, pp. 1007 1016, 2016

[18] C. S. Poon, A. T. W. Yu, L. Jaillon, "Reducing building waste at construction sites in Hong Kong", Construction Management and Economics, Vol. 22, No. 5, pp. 461-470, 2004

[19] H. Maniam, S. Nagapan, A. H. Abdullah, S. Subramaniam, S. Sohu, "A comparative study of construction waste generation rate based on different construction methods on construction project in Malaysia", Engineering, Technology \& Applied Science Research, Vol. 8, No. 5, pp 3488-3491, 2018

[20] N. Kartam, N. A. Mutairi, I. A. Ghusain, J. A. Humoud, "Environmental management of construction and demolition waste in Kuwait", Waste Management, Vol. 24, No. 10, pp. 1049-1059, 2004

[21] S. D. Sawaitul, K. P. Wagh, P. N. Chatur, "Classification and prediction of future weather by using back propagation algorithm: An approach", International Journal of Emerging Technology and Advanced Engineering, Vol. 2, No. 1, pp. 110-113, 2012

[22] D. Stanley, D. McGowan, S. H. Hull, "Pitfalls of Over-Reliance on Cross Multiplication as a Method to Find Missing Values", Texas Mathematics Teacher, Vol. 11, No. 1, pp. 9-11, 2003

[23] A. A. Mustaffa, M. F. Hasmori, A. S. Sarif, N. F. Ahmad, N. Y. Zainun, "The Use of UAV in Housing Renovation Identification: A Case Study at Taman Manis 2", IOP Conference Series: Earth and Environmental Science, Vol. 140, Article ID 012003, 2018 